\author{
Yohanes Karyadi Kusliansjah ${ }^{1}$, Eva Priyanti ${ }^{2}$ \\ Universitas Katolik Parahyangan \\ ${ }^{1}$ karyadi@unpar.ac.id \\ ²evapriyanti123@gmail.com
}

\title{
INOVASI DESAIN DALAM MEWUJUDKAN KELAYAKAN LINGKUNGAN PERUMAHAN DAN PASAR PADAT TEPI SUNGAI KOTA

\author{
KASUS: LINGKUNGAN PASAR ASTANA ANYAR, PUSAT KOTA \\ BANDUNG
}

\begin{abstract}
The emergence of spilled markets and dense residential neighborhoods on the river banks in Astana Anyar, is one of the impacts that caused by land crisis phenomenon occurred in the city center of Bandung. Astana Anyar market and dense housing conditions fueled the emergence of a slum environment. Standing between two rivers and low land contours causes Astana Anyar market and the surrounding housing environment have a huge threat of flooding due to river floods during heavy rains and exacerbate existing environmental conditions.

Standing in the city center of Bandung, Astana Anyar market and the surrounding housing location area have an opportunity of building structures toward vertical buildings and development feasibility on high-value land locations that meet market prices in the city center.

Degradation of environmental conditions that occur, causing housing conditions to be unfit and unhealthy for the community. In addition, Astana Anyar market also experienced a decline in its quality as one of the important economic drivers. In this condition, Astana Anyar market and the surrounding housing environment need an innovative solution to structuring the dense residential and market environment.

By conducting direct observation and interviews to the local community and market users, this research attemps to examine deeper about the problems and potential that exist, so that could be used as a reference formulation of design innovation solutions that could be done as an effort to structuring the dense housing and market to be sustainable environment.
\end{abstract}

Keywords: Vertical building, land crisis, sustainable environment, slums, dense housing.

\section{PENDAhuluan}

Tempat tinggal merupakan salah satu kebutuhan pokok penduduk kota yang secara langsung mempengaruhi kepadatan spasial kota. Semakin banyak jumlah populasi penduduk yang tinggal, tentunya berbanding searah dengan kebutuhan tempat tinggal yang harus disediakan. Luas kota yang akan tetap sama, harus mewadahi kebutuhan jumlah luasan tempat tinggal yang terus bertambah jumlahnya. Hal ini tentunya berdampak pada timbulnya krisis lahan di kawasan kota karena lahan yang layak dan strategis untuk dihuni semakin berkurang. Krisis lahan di kawasan kota juga berdampak pada meningkatnya nilai lahan, terutama pada kawasan-kawasan strategis.

Mahalnya harga lahan di kawasan strategis di kota, mendorong munculnya kantongkantong pemukiman kumuh di tengah kota. Pendapatan penduduk kota tentunya tidak semua sama, masyarakat yang memiliki penghasilan yang relatif lebih rendah, tidak mampu membeli lahan yang mahal dan terpaksa mendirikan tempat tinggal secara illegal di kawasan-kawasan strategis yang dekat dengan sumber mata pencahariannya.

Munculnya pemukiman padat seperti ini muncul di lingkungan pasar Astana Anyar yang berada di jalan Astana Anyar, kelurahan Nyengseret, kecamatan Astana Anyar, pusat kota Bandung. Pasar Astana Anyar merupakan salah satu pasar tradisional yang sudah tergolong tua, yaitu didirikan pada tahun 1975. Sebelum pasar itu berdiri, sudah terdapat aktifitas informal berupa pedagang kaki lima yang menjual barang-barang loak. Aktifitas informal ini lah yang berhasil mendorong kawasan ini semakin hidup dan kemudian didirikan pasar sebagai sarana mata pencaharian dan mendapat bahan makanan pokok. Aktifitas pasar loak ini terjadi di depan 
pasar dan di sepanjang jalan Astana Anyar. Setiap pagi hingga siang hari, jalan penuh sesak oleh lapak penjual barang loak, dan terkadang barang dagangan lainnya ikut turut serta membuka lapak dagangannya. Pada pagi hari hingga siang, dapat dirasakan ramainya suasana di pasar Astana Anyar, bahkan terkadang menimbulkan kemacetan.

Mayoritas masyarakat yang tinggal di perumahan sekitar pasar berdagang dan bekerja di pasar. Selain berdagang dan bekerja di pasar, banyak juga masyarakat yang berbelanja grosir kelontongan untuk dijual lagi di rumah sebagai mata pencaharian ibu rumah tangga. Hal ini berdampak pada banyaknya rumah yang memiliki kios untuk membuka lapak kelontongan di rumahnya. Beberapa rumah juga memiliki gudang penyimpanan barang dagangan. Dengan ukuran rumah yang kebanyakan sempit, fungsi kios dan gudang penyimpanan barang dagangan cukup terasa memakan ruang rumah sebagai ruang istirahat dan berkumpul keluarga.

Namun, dibalik hubungan yang saling menguntungkan ini, lahan pasar dan sekitar pasar yang merupakan lahan pemerintah, difungsikan sebagai tempat tinggal yang tidak tertata. Jarak antara rumah satu dengan yang lainnya hampir seluruhnya dijadikan sebagai koridor jalan sempit dan merupakan satu satunya akses yang ada. Sangat sulit ditemukan ruang terbuka hijau di lingkungan perumahan sekitar pasar Astana Anyar, rumah-rumah penduduk berkumpul penuh sesak di dalam area yang sempit.

Dengan kondisi lingkungan yang kotor, kurang ruang terbuka hijau, akses yang kurang layak, lingkungan perumahan akan memberi dampak bagi kesehatan masyarakat yang tinggal di lingkungan ini. Masyarakat akan dengan sangat mudah terkena bakteri dan virus yang ada pada sampah yang berserakan di tepi koridor-koridor jalan depan rumah mereka.

Minimnya ruang terbuka hijau juga memberi dampak terhadap kurangnya udara bersih yang dapat mereka hirup sehari-hari. Adanya pasar Astana Anyar yang berdiri di antara lingkungan perumahan dan jalan Astana Anyar, cukup mengisolasi perumahan, karena masyarakat harus melewati koridor pasar terlebih dahulu sebelum masuk ke lingkungan perumahan. Jalan juga tidak bisa diakses oleh kendaraan roda empat, dan mobil pemadam kebakaran, sehingga hanya dilalui oleh sepeda motor dan pejalan kaki. Dari sisi jalan raya yang lain, lingkungan perumahan di sekitar pasar Astana Anyar juga tertutup oleh bangunanbangunan lain, seperti bangunan pertokoan, dan perumahan-perumahan lain yang hanya menyediakan akses jalan sempit sekitar 1 meter untuk keluar masuk lingkungan perumahan sekitar pasar Astana Anyar.

Degradasi kualitas lingkungan tidak hanya terjadi di lingkungan perumahan saja, kondisi fisik pasar yang merupakan salah satu sarana ekonomi paling penting bagi masyarakat, saat ini hanya $40 \%$ saja. Secara sekilas, pasar terlihat kotor dan penuh sesak oleh kios dan meja pedagang yang tidak tertata dengan baik, selain itu, bau tidak sedap juga sangat tercium saat berada di dalam pasar.

Setelah kurang lebih 42 tahun berdiri di pusat kota Bandung, pasar hanya mengalami dua kali renovasi, yaitu pada tahun 1993 dan 1999. Namun, renovasi yang dilakukan pada tahun 1999, sepertinya masih belum mampu menghasilkan perubahan yang signifikan untuk kemajuan pasar. Renovasi pada tahun 1999, meninggalkan ruang dagang yang tidak difungsikan untuk berdagang. 


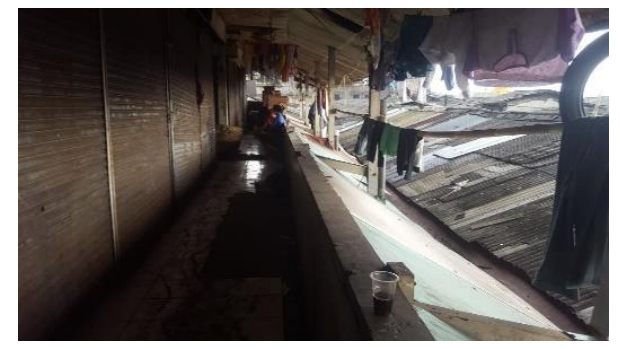

Lantai 2 yang seharusnya diperuntukkan untuk komoditi keringan dan fashion, justru digunakan sebagai kos atau tempat tinggal sewa bagi pedagang pendatang, dan sebagian difungsikan sebagai gudang. Kios-kios yang seharusnya difungsikan sebagai ruang dagang, justru terlihat berantakan dengan alat-alat rumah tangga dan jemuran pakaian yang tidak tertata.

Gambar 1. Kondisi Lantai 2 Pasar Astana Anyar

Dari tahun ke tahun jumlah pengunjung yang berbelanja di pasar Astana Anyar semakin sepi. Hal yang menyebabkan pasar Astana Anyar semakin sepi kemungkinan adalah banyaknya pasar-pasar baru yang menyediakan fasilitas lebih bersih dan tertata. Pasar Astana Anyar sebagai pasar tradisional yang sudah lama berdiri, akan terancam ditinggal oleh pelanggan.

Berada di pusat kota Bandung dan memiliki nilai lahan yang tinggi, serta pentingnya peran pasar Astana Anyar sebagai pasar kecamatan, kondisi lingkungan pasar Astana Anyar saat ini sangat perlu untuk dilakukan pembenahan penataan lingkungan guna menjadikan lingkungan pasar Astana Anyar mampu berkembang menjadi lingkungan yang lebih baik. Pasar tradisional yang terkenal dengan komoditi daging dan barang loaknya, serta aktifitas yang harmonis antara pasar dan perumahan di sekitarnya yang membentuk sebuah kampung, merupakan aset kota yang harus dipertahankan dan dikembangkan dengan sebuah inovasi penataan lingkungan padat dan kumuh yang mampu menjawab tantangan pertumbuhan pembangunan berkelanjutan.

Lingkungan pasar Astana Anyar dan perumahan di sekitarnya merupakan lahan pemerintah di tengah kota yang di kedua sisinya di aliri oleh dua sungai, yaitu sungai Citepus dan sungai Cikakak. Namun, sungai Citepus dan Cikakak yang sekaligus sebagai tepi lingkungan, juga memberi ancaman banjir karena kontur tanah lingkungan pasar Astana Anyar dan perumahan di sekitarnya tergolong rendah, sehingga pada musim hujan sering terjadi banjir. Saat hujan deras, air sungai meluap dan membanjiri lingkungan pasar dan perumahan di sekitarnya.

Rumah-rumah didirikan dengan jarak yang begitu dekat dengan sungai, sehingga secara teknis perumahan melanggar garis sepadan sungai. Rumah dan sungai hanya dipisahkan oleh koridor jalan dengan lebar sekitar 1 meter saja. Hal ini turut berperan dalam semakin bertambahnya potensi banjir yang dapat terjadi karena kurangnya area peresapan air hujan dan juga vegetasi, hampir seluruh lahan di sekitar sungai dibangun rumah dan koridor jalan yang diberi perkerasan dengan paving dan juga plesteran.

Meskipun rawan banjir, namun perumahan dan pasar Astana Anyar tetap dibangun secara horizontal, padahal pada RDTR kota bandung, area perumahan di sekitar pasar Astana Anyar di Peruntukan sebagai perumahan kepadatan tinggi dengan KDB 40\% dan KLB 3,6, sehingga dapat memungkinkan untuk di bangun bangunan perumahan dengan luas lantai bangunan hingga $50.400 \mathrm{~m}^{2}$ dengan lantai dasar mencapai $5.600 \mathrm{~m}^{2}$. Namun, pada kenyataannya, pada saat ini luas lantai yang terbangun mungkin hanya 25\% dari luas lantai yang diizinkan. Sedangkan area pasar diperuntukan sebagai bangunan campuran intensitas tinggi dengan KDB 65\% dan KLB 6,5 sehingga dapat memungkinkan untuk di bangun bangunan perumahan dengan luas lantai bangunan hingga $65.000 \mathrm{~m}^{2}$ dengan lantai dasar mencapai $6.500 \mathrm{~m}^{2}$, dan saat ini hanya terbangun sekitar $20 \%$ dari luas lantai yang diizinkan. Dengan luas lahan yang terbatas, dan luas lantai yang masih belum dioptimalkan, pembangunan ke arah vertikal sangat memungkinkan untuk dilaksanakan sebagai upaya memaksimalkan nilai bangunan agar sesuai dengan nilai lahannya yang sangat tinggi. 
Namun, pada kenyataannya saat lingkungan perumahan dan pasar Astana Anyar masih terus mengalami degradasi kondisi lingkungan, kondisi bangunan perumahan dan pasar yang padat semakin turun kualitasnya, bangunan dibiarkan penuh sesak tanpa adanya ruang terbuka, bangunan dan jalanan yang sering tergenangi air luapan sungai, dinding yang semakin keropos, dan lantai yang dibiarkan becek. Hal ini menyebabkan perumahan menjadi lingkungan yang tidak layak huni dan sehat bagi masyarakat. Selain itu, pasar tradisional yang harus dijaga juga kian turun kualitasnya sebagai penggerak ekonomi yang penting bagi masyarakat sekitar.

Terjadi peningkatan terhadap pengembangan konsep mix use untuk merespon tantangan urbanisasi, perubahan iklim, dan bencana alam (Pamela, 2014). Selain itu, pada penelitian sebelumnya, menyatakan bahwa konsep mix use lebih berkelanjutan jika dibandingkan dengan konsep single use (Beyer 2006). Zonasi mix use merupakan gabungan dari beberapa jenis penggunaan lahan di dalam satu area (Beyer 2006) [...] sejauh mana penggunaan lahan dapat atau tidak dapat dicampur dalam wilayah tertentu ditentukan oleh kode zonasi kota. Sebagian besar kota sudah menetapkan beberapa klasifikasi penggunaan lahan yang berbeda dalam kode zonasi mereka [...] (Beyer 2006). Konsep mix use merupakan konsep yang praktis dan berkelanjutan baik di tingkat individu maupun pada tingkat masyarakat yang lebih luas, yaitu dengan mengurangi ketergantungan individu pada moda transportasi yang mahal dan memakan waktu yang menyedot sumber daya dari investasi jangka panjang [..] dalam pengertian yang lebih luas, mix use juga merupakan alat untuk membangun komunitas yang kohesif dan awet. Hal ini membawa masyarakat kepada lingkungan pejalan kaki secara bersama-sama dan memungkinkan mereka berinteraksi secara tatap muka baik secara sosial maupun profesional. (Speck, n.d.). Alasan-alasan inilah yang menyebabkan penerapan konsep mix use menjadi semakin digalakkan (PAMELA 2014).

Belanda, dengan berani mengembangkan konsep mix use secara vertikal, yaitu pada Markthal Rotterdam. Bangunan merupakan gabungan dari fungsi apartemen yang melingkupi pasar makanan segar berupa kios-kios makanan, restaurant, supermarket, dan parkiran bawah tanah yang belum ditemukan di manapun (Archdaily, 2014). Pasar memiliki karakteristik yang unik yang berbeda dengan supermarket dan mall. Pasar menawarkan 'sense of experience' melalui karakteristik fisik, ruang, produk dan layanan, yang mencerminkan gaya hidup dari komunitas lokalnya (TRAX and Stead, 2010; Weiss, 1998 cheated by Zulaikha) sehingga dapat dikatakan bahwa pasar merupakan suatu fungsi publik, yang sangat berbeda dengan fungsi apartemen yang cenderung bersifat privat.

Kompatibilitas pada penggunaan tertentu akan sangat dipengaruhi oleh bentuk dan/ atau skala dari pengembangan mix use (APA 2013). Selain itu, terutama pada proses revitalisasi suatu area urban memiliki karakter unik yang tidak mudah untuk direplikasi, hal ini sebabkan oleh adanya pengaruh konteks yang sangat kuat, terutama pada konteks lokal dari generasi ke generasi (PAMELA 2014). Tantangan terbesar dalam mengembangkan konsep pencampuran fungsi yang berbeda ini adalah bagaimana menggabungkan beberapa fungsi dengan karakteristik yang sangat berbeda menjadi satu kesatuan utuh dalam satu bangunan, mengingat pasar tradisional dan apartemen memiliki pola aktivitas yang sangat berbeda di dalamnya. Selain itu, bangunan juga harus menunjukkan nilai-nilai yang ada dalam konteksnya.

Lingkungan pasar Astana Anyar merupakan salah satu lingkungan tengah kota Bandung yang mengalami penurunan kondisi fisik yang secara tidak langsung mempengaruhi produktifitas masyarakat setempat. Lingkungan pasar Astana Anyar juga merupakan salah satu titik prioritas pembangunan di kota Bandung karena kondisi pasar yang hanya $40 \%$ dan dikelilingi oleh perumahan ilegal yang juga berdiri di sepanjang sempadan sungai. Keterbatasan lahan di tengah kota Bandung merupakan masalah utama yang memicu munculnya 
kemerosotan kondisi lingkungan akibat kurangnya ruang terbuka hijau dan lahan sebagai infrastruktur lingkungam Sangat disayangkan apabila lingkungan pasar Astana Anyar terus dibiarkan menurun kondisinya, karena lingkungan pasar Astana Anyar memiliki beberapa potensi yang harus dikembangkan untuk kesejahteraan masyarakat setempat, yaitu sebagai berikut:

a. Adanya pranata pembangunan yang memungkinkan adanya optimalisasi perluasan lantai ke arah vertikal untuk memaksimalkan nilai bangunan hingga 10 lantai.

b. Mengalirnya sungai Citepus dan Cikakak yang memberi ancama banjir terhadap lingkungan perumahan dan pasar dapat di jadikan potensi sebagai riverfront kota apabila ditata dan dikelola dengan lebih baik.

c. Pasar Astana Anyar merupakan pasar kecamatan yang memiliki komoditi unggulan berupa olahan daging yang sudah terkenal. Keunggulan ini harus terus dikembangkan untuk kesejahteraan pedagang dan pengolah daging.

d. Selain komoditi unggulan berupa olahan daging, pasar Astana Anyar juga memiliki PKL barang-barang loak yang sudah sangat terkenal hingga ke seluruh nusantara. PKL pasar loak ini memberikan kekhasan untuk pasar Astana Anyar serta menarik banyak pengunjung.

e. Sebagai pasar tradisional kelas I yang menjual banyak barang jualan basah, pasar Astana Anyar menghasilkan banyak sampah organik. Dengan pelatihan dan pengolahan yang baik, sampah organik yang dihasilkan dapat dimanfaatkan masyarakat setempat sebagai tambahan penghasilan.

Mengacu kepada Inpres No. 5 tahun 1990 mengenai pedoman pelaksanaan peremajaan permukiman kumuh di atas tanah negara, yang menyatakan bahwa pertimbangan peremajaan permukiman kumuh adalah dalam rangka mempercepat peningkatan kualitas kehidupan masyarakat, terutama bagi golongan masyarakat berpenghasilan rendah yang bertempat tinggal di kawasan permukiman kumuh yang berada di atas tanah negara. Peremajaan permukiman kumuh dalam Inpres No. 5 tahun 1990 tersebut meliputi pembongkaran sebagian atau seluruh permukiman kumuh yang sebagian besar atau seluruhnya berada di atas tanah negara dan kemudian di tempat yang sama dibangun prasarana dan fasilitas rumah susun serta bangunanbangunan lain sesuai dengan rencana tata ruang kota yang bersangkutan.

Selain itu, dengan adanya peluang dari RDTR kota Bandung, dimana, lahan pasar Astana Anyar diperuntukkan sebagai fungsi campuran dengan intensitas tinggi, sehingga, peremajaan diarahkan kepada bangunan rumah susun yang ditumpangkan di atas fungsi pasar tradisional Astana Anyar. Dengan peluang-peluang tersebut, konsep Mix Use merupakan konsep yang sangat sesuai untuk diterapkan pada mengembangan lingkungan pasar Astana Anyar.

\subsection{Permasalahan}

Dengan kondisi yang ada, lingkungan pasar Astana Anyar dan perumahan di sekitarnya membutuhkan suatu solusi inovasi desain penataan lingkungan perumahan dan pasar padat agar mampu menjadi lingkungan yang berkelanjutan dengan memanfaatkan peluang dan potensi yang ada.

\subsection{Tujuan Penelitian}

Tujuan dari penelitian terhadap lingkungan pasar Astana Anyar dan perumahan di sekitarnya adalah untuk memahami lebih dalam mengenai permasalahan dan potensi yang ada, sehingga dapat dijadikan sebagai acuan perumusan solusi inovasi desain yang dapat dilakukan sebagai upaya penataan lingkungan perumahan dan pasar padat agar mampu menjadi lingkungan yang berkelanjutan.

Fokus penelitian ini adalah mengkaji lebih dalam mengenai potensi dan permasalahan yang ada pada lingkungan pasar Astana Anyar, yang meliputi Pasar Astana Anyar, dan 
perumahan ilegal di sekitarnya. Potensi dan permasalahan dikaji baik dari aspek fisik, dan non fisiknya yang selanjutnya dianalisis dengan menggunakan Commercial and Mixed-Use Development Code Handbook untuk mengetahui aspek-aspek yang menentukan keberhasilan dalam penerapan konsep Mix Use.

\section{Lingkup Penelitian}

Penelitian akan berfokus pada kondisi fisik pasar Astana Anyar dan lingkungan perumahan di sekitarnya, yaitu bagaimana kondisi fisik ini mempengaruhi aktifitas sosial dan ekonomi masyarakat setempat, mengingat hubungan di antara keduanya yang sangat erat.

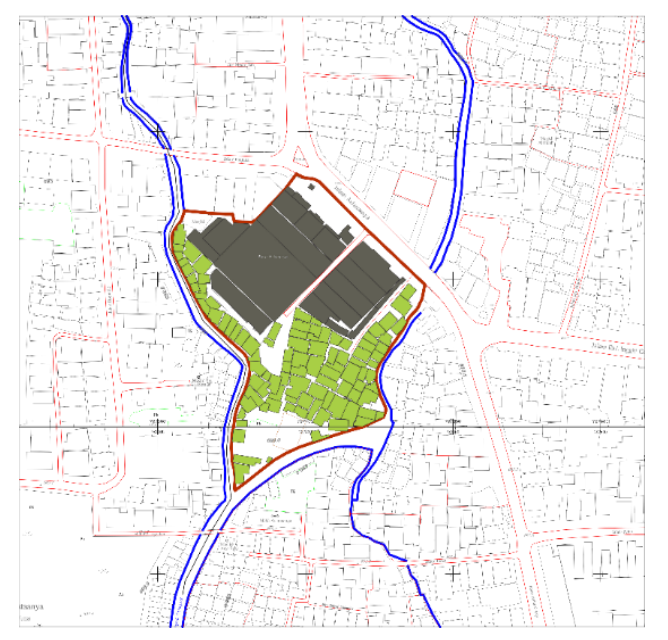

Warna abu-abu merupakan posisi pasar Astana Anyar, warna hijau merupakan posisi lingkungan perumahan sekitar pasar, dan warna biru merupakan sungai Citepus dan Cikakak yang mengalir di tepi lingkungan objek penelitian.

Gambar 2. Ilustrasi Lokasi Objek Penelitian

Sumber: Dokumentasi Distarcip (teredit)

\section{Kajian Literatur}

\subsection{Kebutuhan Manusia Terhadap Hunian}

Rumah merupakan salah satu kebutuhan pokok manusia, karena rumah merupakan tempat tinggal bagi manusia dan berlindung dari ancaman dari luar, seperti panas dan hujan, penjahat, serta binatang. Pada dasarnya, di dalam rumah manusia akan membutuhkan dua hal pokok, yaitu aktifitas fisiologis dan sosialisasi. Secara fisiologis, di dalam rumah, manusia membutuhkan udara yang sehat untuk dihirup setiap detiknya, manusia juga membutuhkan sarana untuk dapat tidur, bersitirahat, dan bersantai dengan nyaman. Pada aktifitas sosiolisasi, rumah merupakan tempat utama bagi manusia untuk membina keluarga, di dalamnya terjadi aktifitas mendidik, dan bercengkrama dengan keluarga.

Sebagai kebutuhan pokok bagi manusia, rumah sangat erat hubungannya dengan kebutuhan dasar manusia, berikut adalah hirarki kebutuhan dasar manusia terhadap huniannya: (Maslow dalam Newmark et al, 1977):

a. Physiological Needs (food, water, air)

Kebutuhan fisiologis merupakan kebutuhan dasar manusia, dimana manusia akan selalu membutuhkan udara bersih untuk bernafas, tidur, dan lain-lain. Untuk memenuhi kebutuhan itu, rumah seharusnya menyediakan ruang yang yang memungkinkan udara bersih masuk ke dalam, serta ruang tidur yang nyaman untuk beristirahat.

b. Safety Needs (security, stability, protection, order)

Rumah merupakan sarana manusia untuk berlindung. Rumah harus mampu memberi perlindungan dari panas matahari, dan udara dingin. Selain itu, manusia juga membutuhkan rasa aman dari gangguan penjahat dan binatang.

c. Belongingness and Love Needs (love, affection, sense of belonging) 
Rumah adalah tempat di mana keluarga akan berkumpul, di sinilah setiap anggota keluarga akan merasa dicintai, dan diterima. Manusia membutuhkan ruang interaksi yang nyaman untuk saling berbagi.

\section{d. Esteem Needs (self respect, independence, esteem from others)}

Tunawisma merupakan predikat yang semua orang mungkin tidak mengharapkan mendapat predikat tersebut. Untuk itu, rumah merupakan sesuatu yang penting untuk mengangkat martabat seseorang, bahwa seseorang itu memiliki tempat tinggal dan tujuan pulang.

\section{e. Self Actualization (Self Fulfillment)}

Manusia membutuhkan pengakuan. Bisa dikatakan, kebutuhan ini merupakan kebutuhan tersier, di mana rumah dijadikan sarana bagi manusia untuk menunjukkan kepada dunia luar, siapakah dirinya. Rumah akan mencerminkan siapa orang yang memilikinya, sehingga, secara tidak langsung orang dapat menilai bagaimana karakter, status sosial, dan selera pemilik rumah.

\subsection{Kebutuhan Manusia Terhadap Pasar}

Keberadaan pasar tradisional pada suatu lingkungan, memiliki beberepa peran, yaitu sebagai berikut:

\section{a. Peran Pasar Tradisional dalam Aspek Ekonomi}

Berbeda dengan pasar modern, pasar tradisional di Indonesia kebanyakan adalah milik pemerintah yang dikelola oleh Dinas Pasar, (Suryadarma \& Mcculloch, 2007). Pasar diperuntukkan bagi pedagang-pedagang lokal untuk menjual barang dagangannya dengan harga yang lebih murah dibanding dengan pasar modern, sehingga harga yang ditawarkan memungkinkan pembeli untuk menjualnya lagi (grosir). Pasar tradisional biasanya difungsikan sebagai sarana untuk memperdagangkan hasil tani masyarakat lokal berupa beras, dan sayursayuran. Selain itu juga hasil ternak, seperti daging sapi, ayam, dan hasil olahannya.

Selain itu, pasar tradisional juga mendorong pembeli untuk tidak hanya berbelanja di pasar saja, tetapi juga berbelanja di toko yang ada di sekitar pasar. Sehingga, pasar seharusnya tidak dianggap sebagai sarana persaingan antar toko, namun sebagai pelingkup seluruh pedagang yang ada, (Dobbin Labour Co-op \& Bill Olner, 2009). Dengan membentuk perkumpulan, pedagang lokal akan lebih menarik untuk dikunjungi, karena masing-masing pedagang akan saling melengkapi satu sama lain, sehingga pembeli yang berbelanja akan berbelanja secara lengkap sesuai daftar belanja yang telah disusun.

Dengan manfaat-manfaat tersebut, dapat disimpulkan bahwa pasar sangat berperan penting untuk perekonomian masyarakat lokal untuk menjual hasil tani, ternak, serta barang dagangan lainnya. Penawaran harga yang lebih murah, membuat pasar tradisional juga berperan dalam membantu masyarakat untuk membuka usaha retail, yaitu dengan menjual kembali barang yang dibeli di pasar secara eceran.

b. Peran Pasar Tradisional dalam Aspek Sosial

Pasar tradisional juga merupakan ruang publik bagi masyarakat. Di mana pasar memiliki kontribusi untuk mendorong keterikatan masyarakat terhadap kelokalannya dan memberi kesempatan mereka untuk bercampur dengan orang lain, (Dines and Cattell et al., 2006, cheated by Worpole \& Knox, 2007). Di pasar, para pedagang berkumpul dan membentuk suatu kesatuan dengan pedagang lain membentuk suatu komunitas. Pedagang datang dari berbagai macam latar belakang dan daerah asal, lalu mereka diberi kesempatan untuk berinteraksi di dalam pasar. Selain itu, pasar juga memberi peluang yang lebih besar bagi para pedagang lokal yang mayoritas pedagang dari daerah kecil, untuk menyampaikan aspirasinya kepada pemerintah melalui komunitas pedagang pasar. Selain sebagai sarana sosialisasi bagi pedagangnya, pasar juga memberi kesempatan bagi pembeli untuk bertemu dengan pembeli lain, dan kemudian berinteraksi satu sama lain. 


\section{Metode Penelitian}

\begin{tabular}{|c|c|c|}
\hline & & Teori \\
\hline \multirow{6}{*}{$\begin{array}{l}\quad \text { Pengumpulan Data } \\
\text { Observasi } \\
\text { Wawancara } \\
\text { Pemerikasaan Dokumen }\end{array}$} & \multirow{6}{*}{$\begin{array}{l}\text { Analisis } \\
\text { Kualitatif } \\
\text { Deskriptif }\end{array}$} & $\begin{array}{l}\text { Commercial and Mixed-Use Development } \\
\text { Code Handbook }\end{array}$ \\
\hline & & \\
\hline & & Compact Development \\
\hline & & Mixed Land Use \\
\hline & & $\begin{array}{l}\text { Pedestrian Access, Satety, and Comtort } \\
\text { Street Connections }\end{array}$ \\
\hline & & $\begin{array}{l}\text { Crime Prevention and Security } \\
\text { Creating and Protecting Public Spaces } \\
\text { Parking and Efficient Land Use } \\
\text { Human Scaled Building Design } \\
\text { Sense of Place }\end{array}$ \\
\hline
\end{tabular}

Gambar 3. Metode Penelitian

Penelitian merupakan penelitian kualitatif deskriptif, yang dijabarkan melalui metode analisis. Data diperoleh melalui observasi langsung terhadap studi kasus, yaitu dengan megobservasi lebih dalam mengenai kondisi fisik dan non fisiknya untuk mengetahui potensi dan permasalahan yang ada. Observasi meliputi pasar Astana Anyar dan 287 rumah ilegal yang berdiri di sekitarnya.

Selain itu, data juga diperoleh dengan melakukan wawancara kepada pihak-pihak terkait, yaitu pengelola pasar, pedagang pasar, serta masyarakat setempat yang tinggal di sekitar pasar. Data juga didukung oleh pemeriksaan terhadap dokumen-dokumen yang ada untuk mendukung penelitian agar lebih dalam.

\section{Hasil \& Pembahasan}

\subsection{Kondisi Lingkungan Perumahan Sekitar Pasar Astana Anyar dalam Memenuhi Kebutuhan Manusia}

a. Ruang Tinggal

Secara dimensi rumah tinggal di perumahan sekitar pasar Astana Anyar sangat beragam. Serta terdapat rumah dengan satu lantai hingga dua lantai. Ukuran masing-masing rumah mayoritas sudah mampu mewadahi ruang tamu, kamar tidur, dapur dan kamar mandi pribadi. Ukurang ruang tinggal tergolong sudah mampu mewadahi sarana untuk kebutuhan fisiologis pengguna.

b. Kualitas Ruang Tinggal

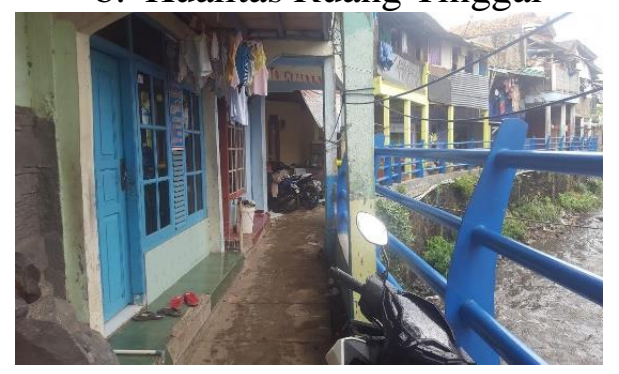

Dari segi kualitas penghawaan, terdapat dua tipe lokasi rumah yang ada, yaitu rumah yang berada di tepi sungai dan rumah di tengah lingkungan. Untuk rumah yang berada di tepi sungai, rumah dihadapkan ke arah sungai, sehingga langsung terhubung dengan ruang terbuka yang luas. Hal ini memungkinkan rumah akan langsung terhubung ke udara luar, sehingga sirkulasi udara lebih lancar. Namun, dengan jarak antar rumah yang terlalu dekat antara satu dengan yang lainnya, menyebabkan setiap rumah hanya memiliki satu 


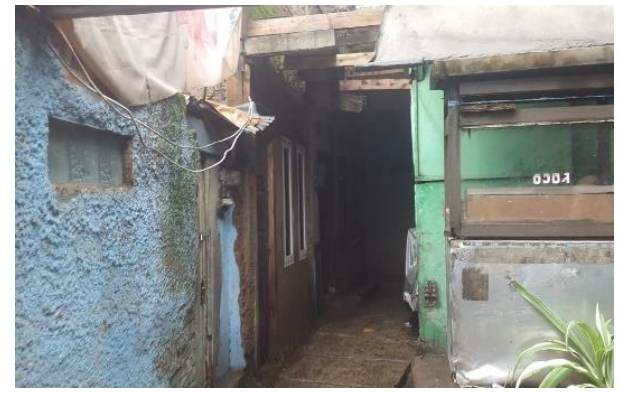

muka bangunan yang dapat di pasang jendela. Hal ini menyebabkan udara luar yang masuk tidak maksimal, karena jendela dan ventilasi yang sangat terbatas. Tidak semua ruangan memiliki jendela untuk memasukan udara, sehingga ruangan menjadi pengap dan kekurangan udara bersih.

Gambar 4. (Kanan) Rumah Tepi Sungai, (Kiri) Rumah di Tengah Lingkungan

Bagitu juga untuk kualitas pencahayaannya, dengan menghadap ruang terbuka, rumah yang menghadap ke sungai akan mendapat cahaya matahari lebih banyak, hanya saja tidak semua ruangan mendapat cahaya matahari alami karena tidak semua ruangan memiliki jendela dan bukaan lainnya.

Dengan lebar koridor jalan yang sangat sempit, dan mayoritas tertutup atap, rumah yang berada di tengah lingkungan tidak terhubung langsung ke area terbuka, sehingga sangat sedikit mendapat udara dan cahaya matahari. Rumah menjadi sangat gelap, dan membutuhkan cahaya lampu hampir sepanjang hari. Selain itu, rumah juga terasa pengap, meskipun sudah terpasang jendela dan ventilasi, namun udara yang masuk kurang bersih dan tidak memungkinkan terjadinya pergantian udara secara lancar karena jendela dan ventilasi hanya terhubung ke koridor jalan yang sempit, sedangkan kanan kirinya sudah tertempel dengan rumah lainnya.

Dari segi kualitas material bangunan rumah, baik rumah yang berada di tepi sungai dan di tengah lingkungan, mayoritas sama. Kebanyakan rumah menggunakan tembok batu bata plesteran yang sebagian dicat dan sebagian tidak. Terdapat juga bagian rumah yang terbuat dari material kayu, yang kebanyakan sudah usang. Tembok bata plesteran yang dicat maupun tidak dicat, kebanyakan dibiarkan begitu saja berjamur dan kotor, begitu juga dengan material kayu yang dibiarkan keropos. Kurangnya perawatan terhadap rumah ini, menyebabkan rumah terlihat kotor.

Secara keseluruhan, kualitas ruang tinggal di perumahan sekitar pasar Astana Anyar masih dinilai kurang. Meskipun mayotitas rumah sudah memiliki ruang tamu, kamar tidur, dapur dan kamar mandi pribadi, namun kualitas ruangnya belum memberi kenyamanan untuk penggunanya. Mereka dapat tidur, tetapi dengan kamar yang pengap, mereka dapat memasak, tetapi dengan bau bumbu yang tidak kunjung hilang, mereka juga dapat bersantai di hari libur, tetapi dengan ruang keluarga yang pengap, dan gelap.

c. Ruang Terbuka pada Rumah

Dengan lahan yang begitu sempit, hampir seluruh rumah tidak memiliki halaman rumah. Rumah hanya memiliki teras kecil sebagai sarana sosialiasi dengan tetangga. Dapat dikatakan, tidak ada rumah di perumahan sekitar pasar Astana Anyar yang memiliki halaman dengan tanaman. Hal ini karena mereka tidak memiliki lahan lebih, rumah langsung berbatasan dengan koridor jalan yang sempit.

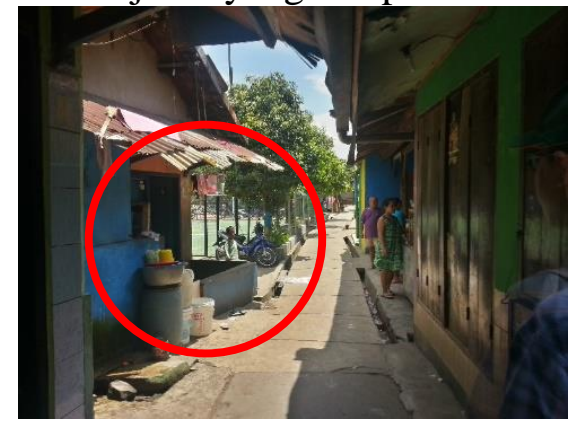

Teras kecil menjadi satu solusi yang banyak digunakan oleh masyarakat, beberapa dari mereka hanya menyediakan kursi atau kotak dari beton sebagai tempat duduk di luar rumah. Kehidupan kampung sangat terasa di lingkungan perumahan Perumahan Sekitar Pasar Astana Anyar, banyak masyarakat yang menghabiskan waktu di sore hari untuk mengbrol dengan tetangga di teras rumah, dengan mengawasi anak anak bermain di koridor jalan. 
Gambar 5. Teras Rumah pada Perumahan Sekitar Pasar Astana Anyar

d. Pembuangan Limbah Rumah Tangga

Limbah rumah tangga dibuang ke beberapa titik pembuangan sampah sementara, karena lahan lingkungan yang begitu sempit, letak pembuangan sampah sangat dekat dengan rumah-rumah warga, sehingga baunya cukup mengganggu. Selain itu, masih banyak rumah tangga yang membuang sampah di koridor depan rumah mereka, sehingga koridor yang sempit semakin terasa sempit dan kotor. Beberapa rumah yang berada di tepi sungai, juga membuang sampah ke sungai, sehingga mencemari sungai Citepus dan Cikakak.

\subsection{Kondisi Pasar Astana Anyar untuk Berperan sebagai Penggerak Ekonomi dan Sarana Sosial Masyarakat}

a. Ruang Dagang

Pasar Astana Anyar memiliki empat jenis ruang dagang, yaitu toko, kios, meja, dan meja selasar. Toko biasanya berisi barang dagangan pakaian, jajanan kering dan aksesoris. Sedangkan kios digunakan sebagai ruang dagang aneka sayur, bumbu, daging, ikan segar dan keringan. Meja dan meja selasar kebanyakan digunakan sebagai ruang dagang daging ayam dalam skala kecil dan aneka jajanan pasar serta buah-buahan. Ukuran ruang dagang ikut menentukan dagangan apa yang tepat untuk dijual di ruang tersebut.Untuk memenuhi kebutuhan rumah tangga sehari-hari, pasar Astana Anyar sudah cukup lengkap untuk belanjaan harian dengan harga yang relatif lebih murah.

b. Kualitas Ruang Dagang

Dari dimensi, ruang dagang cukup mewadahi kebutuhan dagang masing-masing komoditi. Namun, dari segi kualitas ruangnya, material yang digunakan sebagai unit dagang kurang baik.

Unit dagang terbuat dari kayu yang sudah

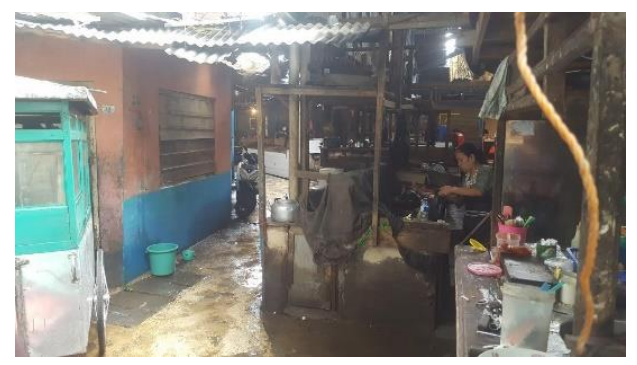
lapuk dan mudah kotor, sehingga unit dagang terlihat reot. Kondisi seperti ini, memberi kesan bahwa barang dagangan yang ditawarkan kurang bersih, terutama untuk barang dagangan basah, seperti daging dan sayuran yang tidak langsung terkemas. Kesan ini secara tidak langsung dapat mempengaruhi psikologi pembeli untuk ragu mengkonsumsi barang dagangan yang dijual. Bagi penjual juga kondisi ini menimbulkan rasa kurang nyaman.

Gambar 6. Ruang Dagang Pasar Astana Anyar

Pada saat menunggu pembeli datang, beberapa pedagang yang menyewa kios atau toko akan istirahat, seperti sekedar tidur-tiduran, tapi istirahat terasa kurang nyaman dengan kondisi kios atau toko yang materialnya kotor, meskipun lantai telah disapu bersih, namun tetap memberi kesan reot. Selain itu, pada area ruang dagang basahan, ruang tidak mereduksi bau daging yang sangat menyengat.

c. Tata Ruang Dagang dan Sirkulasi

Pasar terbagi menjadi dua massa, yang secara keseluruhan konsep pasar adalah dengan massa tunggal, dimana semua ruang dagang dinaungi oleh satu atap yang sama. Konsep ini cukup memberi kenyamanan berbelanja bagi pembeli, karena mayoritas pembeli mengunjungi pasar adalah untuk berbelanja semata, letak ruang dagang pada satu atap sangat efisien, terlebih sangat membantu di saat hujan turun.

Unit dagang ditata dengan pola blok dan disusun dengan susunan grid. Secara susunan, blok cukup efisien, tidak terlalu banyak menghabiskan lantai sebagai koridor, namun setiap 
blok juga tidak terlalu panjang, sehingga persimpangan selasar juga relatif dekat. Namun, penataan kurang nyaman bagi pengunjung karena jenis barang dagangan tidak ditata dengan teratur, misalnya, pakaian dekat dengan daging, kemudian setelah dagangan daging, disebelah terdapat kios aksesoris.

Tidak teraturnya penataan jenis barang dagangan akan menyulitkan pembeli untuk mencari barang yang mereka cari. Selain itu, hal ini juga berpotensi mengurangi kenyamanan apabila, pembeli harus berbelanja pakaian dan buah namun terganggu oleh bau daging yang berasal dari kios sebelahnya.

Kurangnya penataan barang dagang ini kemungkinan juga merupakan sebab toko-toko yang ada di lantai dua pasar sepi dari pedagang, yang justru malah difungsikan sebagai kos (tempat tinggal sewa) pedagang dan gudang. Pada perencanaannya toko-toko di lantai dua di bangun sebagai ruang dagang pakaian, namun pada kenyataannya, kios dan toko pakaian tetap berada di lantai bawah. Mungkin karena kurangnya penertiban yang lebih tegas untuk menentukan dimana blok dagangan basahan, keringan, dan pakaian. Hal ini menyebabkan pasar menjadi kurang efisien dan menampung pedagang dengan lebih optimal.

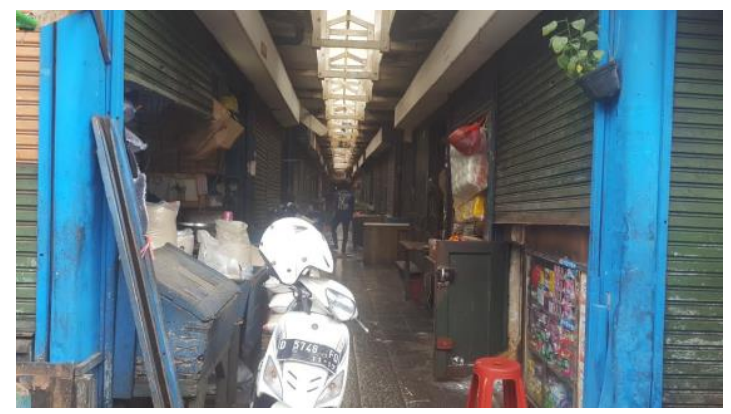

Secara teknis, lebar selasar pasar sudah relatif mencukupi, yaitu sekitar 1,5 meter. Namun, banyak selasar yang dipaksakan untuk menampung meja pedagang, beberapa juga sebagai ekstensi display barang dagangan pedagang. Selain itu, lantai selasar juga kotor, bahkan beberapa becek dan terdapat genangan air.

Gambar 7. Selasar Pasar Astana Anyar

Lebar dan kondisi selasar sangat mempengaruhi kenyamanan pembeli, karena disitulah pembeli melakukan transaksi jual beli, di situlah pembeli juga berinteraksi dengan sesame pembeli untuk besosialisasi. Dengan kondisi selasar yang sempit oleh meja-meja pedagang dan display barang dagangan, pembeli menjadi kurang betah untuk berlama-lama berbelanja dan berkeliling untuk hanya sekedar refreshing.

d. Pembuangan Limbah

Hanya terdapat satu pembuangan sampah sementara yang tersedia, yaitu berada di belakang pasar, yang juga bersebelahan langsung dengan perumahan masyarakat, yang terkadang menuai protes dari masyarakat karena menimbulkan bau kurang sedap. Rencana pengelola untuk melakukan pemilahan sampah, berupa sampah komposter dan biodigester masih belum terlihat sepenuhnya terealisasi, sehingga semua sampah masih terlihat tercampur menjadi satu di tempat pembuangan sampah sementara.

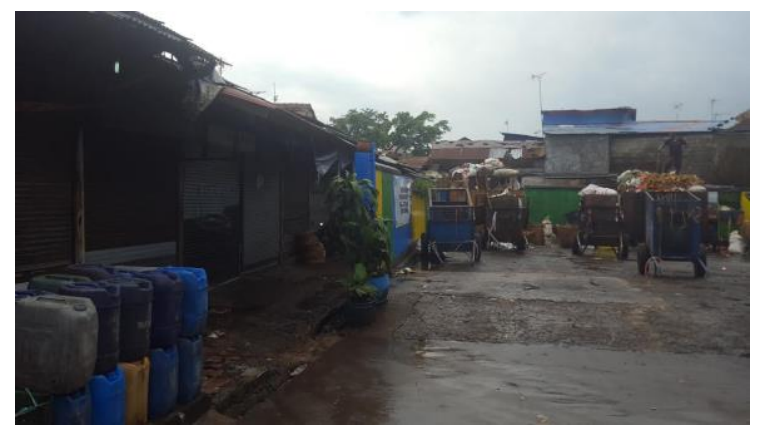

Tempat pembuangan sampah juga tidak menyediakan bak khusus, hanya disediakan lahan terbuka dengan perkerasan plesteran, yang kemudian sampah ditumpuk begitu saja. Hal ini sangat mengganggu pembeli yang berbelanja di dekat tempat pembuangan sampah ini, karena pembuangan sampah menimbulkan bau yang sangat menyengat. 


\section{Gambar 8. Tempat Pembuangan Sampah Sementara Pasar Astana Anyar}

\subsection{Perumahan dan Pasar dalam Membentuk Lingkungan Tepi Sungai}

a. Hampir seluruh bangunan perumahan dan pasar dibangun dengan horizontal, ekstensi ke samping tentunya akan menambah kepadatan spasial. Hal ini menyebabkan bangunan perumahan dibangun dengan sangat rapat dan padat karena bangunan bertambah, namun lahan terbatas. Kerapatan dan kepadatan bangunan ini menyebabkan kurangnya lahan yang dapat dijadikan sebagai ruang terbuka hijau dan mendorong masyarakat untuk melanggar sempadan sungai karena kekurangan lahan untuk membangun rumah.

b. Kerapatan dan kepadatan bangunan juga menyebabkan sulitnya akses di dalam lingkungan karena koridor jalan yang sangat sempit, dan tidak dapat terakses dan dijangkau oleh mobil pemadam kebakaran. Terdapat banyak bangunan rumah yang dibangun dengan material jenis kayu, sehingga akan sangat mudah terbakar jika terjadi kebakaran.

c. Kontur tanah area pasar Astana Anyar dan perumahan di sekitarnya tergolong rendah, sehingga apabila sungai Citepus dan Cikakak meluap, pasar dan perumahan mengalami banjir. Meskipun bukan banjir besar, namun banjir cukup merugikan, ditambah hampir semua ruang bangunan menapak pada tanah.

\subsection{Konsep Mix Use sebagai Inovasi Desain}

Dengan menerapkan konsep mix use untuk menggabungkan fungsi pasar dan perumahan, tantangan terbesar yang harus di hadapi adalah sebagai berikut:

\subsubsection{Permeabilitas}

Sebagai bangunan publik, pasar harus memiliki permeabilitas yang tinggi, yaitu dengan memiliki akses yang baik serta bangunan mampu menarik pengunjung untuk ikut beraktifitas di dalam pasar. Berbeda dengan rumah susun, rumah susun cenderung bersifat lebih privat, yaitu demi menjaga privasi penghuni dan juga keamanan. Privasi rumah susun akan terganggu apabila semua orang dapat mengakses teritori mereka dengan bebas.

\subsubsection{Kebisingan}

Tempat tinggal adalah tempat untuk beristirahat, belajar, dan berkumpul dengan keluarga, sehingga membutuhkan ketenangan. Berbeda dengan pasar yang dapat dikunjungi oleh siapa saja, dan bebas untuk berinteraksi, pasar cenderung bersifat bising, yaitu sekitar $50 \mathrm{db}$ hingga $60 \mathrm{db}$, dimana kebisingan itu disebabkan oleh hiruk pikuk penjual dan pembeli yang melakukan transaksi. Sedangkan rumah susun membutuhkan ketenangan, yaitu dengan ketenangan sekitar $45 \mathrm{db}$ hingga $55 \mathrm{db}$.

\section{Bau}

Hal yang paling berbeda dari karakter pasar tradisional dan hunian adalah bau yang ditimbulkan. Hal ini karena pasar tradisional banyak menjual barang dagangan basah, seperti sayur, buah-buahan, dan daging. Namun, bau didominasi oleh bau 68 unggas, seperti ayam, dan bebek. Berbeda dengan fungsi rumah susun, yang harus bersih dan tidak bau, karena bau akan sangat menggangu.

Untuk mengatasi permasalahan yang kemungkinan akan terjadi tersebut, konsep mix use memiliki aspek-aspek yang mempengaruhi keberhasilan penerapannya, yaitu sebagai berikut:

\section{Compact Development}

Compact Development dilakukan dengan mendorong pemanfaatan infrastruktur kota dengan lebih memanfaatkan fasilitas publik yang ada dan mengurangi kebutuhan fasilitas yang baru dengan membuat bangunan, area parkir, jalan, jalan kendaraan, dan ruang publik dikembangkan menjadi lebih dekat dan dapat dijangkau dengan berjalan kaki dan mengurangi ketergantungan 
terhadap kendaraan, sehingga mampu mengurangi konsumsi lahan, penggunaan energi, dan polusi udara.

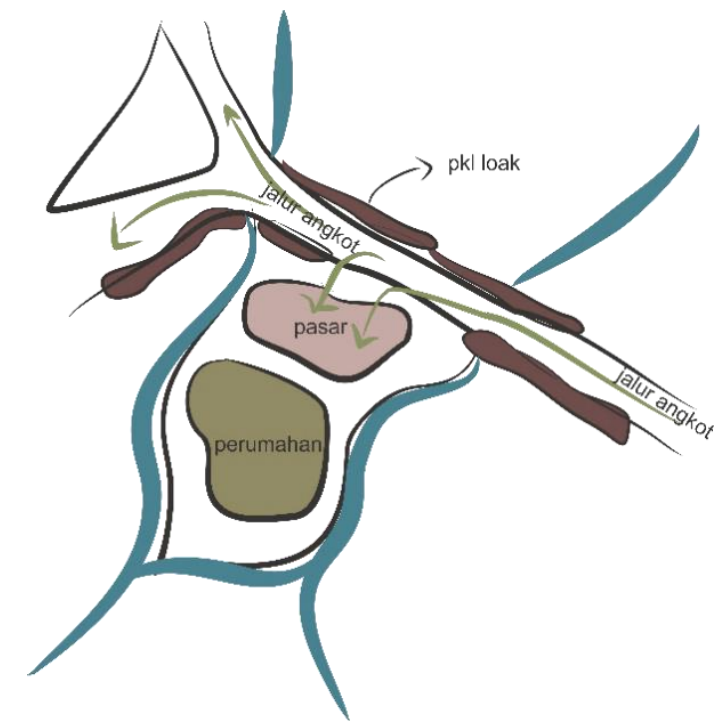

Gambar 9. Ilustrasi Sirkulasi Lingkungan Pasar Astana Anyar

Lingkungan pasar Astana Anyar memiliki 4 fungsi yang harus disusun dengan baik, yaitu pasar, perumahan, PKL dan jalur angkutan umum pada jalan searah. Ke empat fungsi tersebut adalah penggerak aktifitas di area tersebut. Meskipun ke empatnya berjarak berdekatan, namun tidak terdesain dengan baik, sehingga PKL tumpah dijalanan dan perumahan terisolasi oleh keberadaan pasar. Jalur angkutan umum yang begitu mudah, memberikan dampak yang begitu signifikan terhadap pasar, hal ini karena mayoritas pengunjung pasar menggunakan angkutan umum sebagai sarana transportasi. Namun, perlu adanya penanganan terhadap terisolasinya lingkungan perumahan akibat keberadaan pasar, agar penghuni perumahan di sekitar pasar turut menikmati kemudahan akses angkutan umum yang ada.

\section{Mixed Land Use}

Mixed Land Use dilakukan dengan mendekatkan jarak antara fungsi yang cocok pada lokasi yang tepat sehingga dapat memungkinkan untuk dijangkau dengan berjalan kaki, sepeda, dan transportasi umum. Aspek ini perlu memperhatikan beberapa hal, yaitu (1) Kebebasan pergerakan untuk segala usia sehingga nyaman untuk berjalan, bersepeda, dan transit. (2) Menjamin keamanan selama 24 jam. (3) Mengurangi penggunaan kendaraan, terutama untuk jarak dekat. (4) Mendukung masyarakat yang bekerja di rumah, melalu pelayanan dan fasilitas yang dekat. (5) Variasi tipe hunian, sehingga yang muda dan tua, lajang dan berkeluarga, dan memungkinkan masyarakat dengan keberagaman strata ekonomi dapat mendapat tempat untuk hidup.

Berdasarkan kebutuhan fasum fasosnya, area perancangan masih membutuhkan minimal $1000 \mathrm{~m}^{2}$ taman, 5 musholla dan 1 posyandu untuk 287 kepala keluarga, apabila kepadatan dinaikkan, maka kebutuhan juga bertambah. Namun, dengan lahan terbatas, penambahan fasilitas ini tidak memiliki lahan yang cukup untuk melakukan ekspansi secara horizontal. Konsep Mix Use dapat memaksimalkan potensi koefisien luas lantai yang di ijinkan untuk melakukan ekspansi untuk memenuhi kebutuhan ruang yang ada. Dengan penataan program ruang yang baik, hubungan antar fungsi dapat dirancang dengan lebih efisien, efektif, dan nyaman.

3. Pedestrian Access, Safety, and Comfort

Pedestrian Access, Safety, and Comfort dilakukan dengan memungkinkan adanya sirkulasi yang aman, menyenangkan, menarik, dan nyaman bagi pejalan kaki dan pesepeda. Keamanan 
menekankan pada minimalisasi kecelakaan sepeda, kriminalitas, dan ancaman bahaya lainnya, sehingga memberikan rasa nyaman dan bebas untuk berjalan. Desain untuk kenyamanan fisik membutuhkan perhatian pada pengalaman sensori manusia agar meningkatkan minat pengguna. Aspek ini membutuhkan pertimbangan temperature, angina, hujan, cahaya matahari, dan pembayangan untuk kenyamanan pengguna. Selain itu juga perlu mempertimbangkan topografi, kebisingan, polusi dan potensi gangguan lainnya.

Pada area perumahan, akses sangat sempit, luasnya hanya sekitar maksimal 1 meter. Ditambah kondisinya tidak terawat dan beberapa jalan buntu. Dari segi keamanan, jalanan tergolong tidak aman bagi pengguna anak-anak dan lanjut usia, hal ini karena kondisi jalan yang tidak rata dan licin, sehingga sangat berbahaya untuk berjalan kaki dan bersepeda. Selain, dari segi kenyaman, jalan sangat tidak nyaman karena kondisinya kotor dan sempit, serta banyak sampah yang bau. Namun, dengan lahan terbatas sedangkan jumlah rumah masyarakat semakin banyak, tentunya pelebaran jalan tidak dapat dilakukan. Dengan ekspansi menuju arah horizontal, pelebaran akses sangat mungkin untuk dilakukan. Selain dilakukan pelebaran, akses juga harus dirancang dengan baik agar nyaman dan aman untuk digunakan oleh penghuni.

\section{Street Connections}

Street Connections dilakukan dengan menghubungkan pembangunan, lingkungan dan wilayah dengan jalan umum untuk efisiensi transportasi.

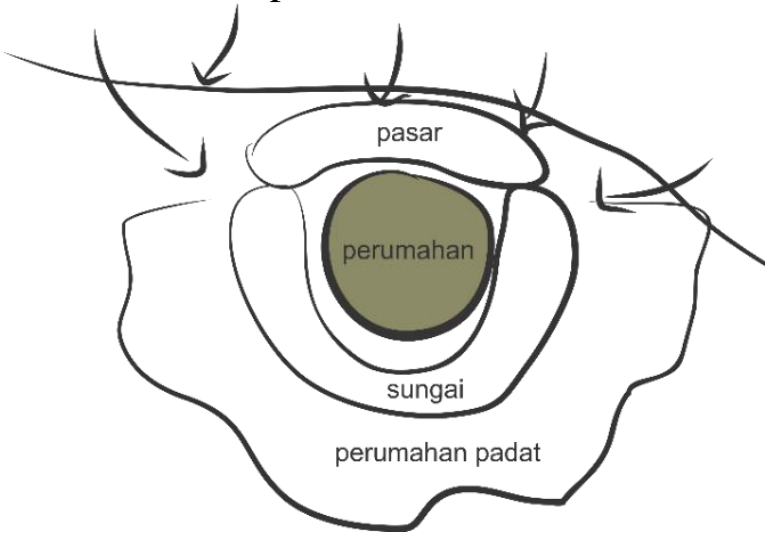

Gambar 10. Ilustrasi Akses Menuju Lingkungan Pasar Astana Anyar

Area perumahan terisolasi oleh keberadaan pasar, dan sungai yang berbatasan dengan perumahan padat. Dengan lahan terbatas, sangat sulit untuk membuka jalan menuju perumahan.

\section{Crime Prevention and Security}

Crime Prevention and Security dilakukan dengan perencanaan dan solusi desain yang meminimalisir kemungkinan untuk terjadinya kriminalitas dan meningkatkan keamanan publik. Hal ini berkenaan dengan pandangan masyarakat yang menganggap bahwa lingkungan yang ramai akan meningkatkan kriminalitas, vandalism, pencurian, kebisingan silau, dan masalah parkir. Pencegahan kriminalitas ini dapat dukung oleh prinsip-prinsip sebagai berikut: (1) Territoriality, yaitu pemisahan antara ruang publik, ruang semi publik, dan menciptakan rasa memiliki dan rasa kewajiban untuk memeliharanya. (2) Natural Surveillance, yaitu banyaknya kemungkinan seseorang untuk berhak terlibat dalam mengawasi area sekitar mereka untuk kemanan mereka sendiri serta kemanan bagi yang lainnya. (3) Access Control, yaitu dengan mempertegas dan mendorong akses publik yang tepat. Selain itu, kontrol akses juga dengan jelas dideliniasi dengan fitur desain yang penting untuk keamanan publik atau untuk mencegah kriminalitas. (4) Activity Support, yaitu dengan merencanakan terjadinya aktivitas pada suatu ruang. (5) Maintenance, pemilihan material dan instalasi harus mempertimbangkan 
perawatan yang mudah, hal ini karena kriminalitas lebih banyak terjadi pada area dengan fasilitas yang tidak terawat.

Dengan kondisi rumah yang sangat padat, jalanan sempit, buntu, dan tidak terawat, namun kondisi lingkungan tergolong aman, karena masyarakat setempat tergolong guyub. Namun, hal ini tidak berarti bahwa lingkungan akan selamanya terbebas dari ancaman kriminalitas. Bukan hanya kejahatan, namun juga resiko adanya pemanfaatan sudut jalan yang buntu dan sepi dimanfaatkan sebagai tempat kegiatan negative seperti tempat mengkonsumsi narkotika, dan lain-lain. Sangat perlu dilakukan perbaikan kondisi jalan yang terawatt dan tidak buntu, namun, seperti pada permasalahan Pedestrian Access, Safety, and Comfort, keterbatasan lahan menyebabkan sulitnya penanganan pada jalan.

\section{Creating and Protecting Public Spaces}

Creating and Protecting Public Spaces dilakukan dengan menciptakan, memelihara, dan meningkatkan ruang publik, seperti bahu jalan, plaza, parkir, bangunan publik, dan ruang berkumpul, untuk memungkinkan terjadinya pertemuan informal dan interaksi sosial dengan orang lain. Menciptakan ruang publik memungkinkan seseorang untuk membentuk suatu organisasi seperti pasar tumpah, atau perkumpulan informal untuk mendapat aktivitas sosial yang penting dan diinginkan. Tipe kegiatan ini tergantung kepada jumlah kehadiran seseorang pada suatu lingkungan fisik yang sama, baik itu di trotoar, atau di plaza. Untuk menciptakan suatu pengalaman yang positif, dibutuhkan keamanan, hal yang menarik, dan nyaman.

Hampir tidak dapat ditemukan ruang terbuka hijau dan ruang publik pada area perancangan. Seluruh ruang sudah terbangun oleh perumahan kumuh dan pasar. Bahkan, sempadan sungai juga sudah terbangun oleh perumahan kumuh. Dengan lahan yang sangat terbatas, dimana diseluruh kanan kiri area merupakan lahan padat, sangat sulit untuk menyediakan ruang terbuka hijau dan juga ruang publik.

\section{Parking and Efficient Land Use}

Parking and Efficient Land Use dilakukan dengan merancang dan mengatur area parkir secara efisien yaitu dengan meminimalisir ruang parkir yang tidak diperlukan.

Masyarakat perumahan tidak memiliki ruang parkir, seluruh masyarakat setempat tidak memiliki kesempatan untuk menyimpan mobil, karena kondisi jalan yang tidak memungkinkan, dan juga tidak adanya lahan. Masyarakat hanya dapat menyimpan motor di dalam rumah. Untuk pasar, area parkir tumpah hingga bahu jalan, karena area parkir yang disediakan cukup sempit akibat keterbatasan lahan sehingga tidak memungkinkan membuka area parkir yang lebih luas.

\section{Human Scaled Building Design}

Human Scaled Building Design dilakukan dengan merancang bangunan dengan skala manusia untuk keindahan yang menarik, kenayamanan pejalan kaki, dan sesuai dengan penggunaan lahan lainnya.

Secara skala manusia, lokasi pasar, perumahan, dan fasilitas lainnya sudah cukup dekat satu sama lain. Hanya saja kondisi akses yang tidak layak sehingga kurang nyaman digunakan, baik untuk berjalan kaki maupun bersepeda dan bersepeda motor, dibutuhkan pelebaran dan perbaikan akses.

\section{Sense of Place}

Sense of Place dilakukan dengan mengingkatkan kesadaran kepada pengguna dimana lingkungan merupakan tempat suatu keluarga hidup, membesarkan anak, bekerja, dan berekreasi.

Meskipun kondisinya kumuh dan padat, namun masyarakat setempat betah untuk tinggal disana, hal ini berdasarkan hasil wawancara dengan masyarakat setempat. Hal ini mungkin terjadi akibat perumahan yang muncul secara alami membentuk suatu perkampungan yang 
guyub. Keguyuban inilah yang harus terus dijaga meskipun nantinya akan terjadi perubahan fisik. Namun, karakter guyub masyarakat harus tetap terjaga dengan baik.

\section{Kesimpulan}

Konsep Mix Use merupakan salah satu alternatif konsep yang dapat dijadikan solusi untuk mengatasi permasalahan kemerosotan kualitas lingkungan pasar Astana Anyar yang disebabkan oleh adanya keterbatasan atau krisis lahan di tengah kota. Hal ini karena aspek-aspek yang menentukan keberhasilan penerapannya, mendorong terjadinya efektifitas dan efisensi lahan. Dengan ekspansi pembangunan ke arah vertikal, kepadatan fisik yang terjadi di lingkungan pasar Astana Anyar dapat lebih feasible untuk diatasi. Efektifitas dan efisiensi yang mungkin dapat dilakukan melalui penerapan konsep Mix Use ini, dapat memungkinkan adanya ruang terbuka hijau dan akses yang lebih luas sebagai sarana bagi penghuni lingkungan pasar Astana Anyar. Apabila semua aspek yang menentukan keberhasilan penerapan konsep Mix Use dapat diterapkan dengan tepat, maka pengembangan lingkungan pasar Astana Anyar dapat membawa lingkungan pasar Astana Anyar menuju lingkungan yang berkelanjutan. Hal ini karena aspekaspek yang menentukan berpotensi untuk menciptakan ruang terbuka hijau yang dapat menungkatkan kualitas kesehatan masyarakat, melestarikan sungai Cikakak dan Citepus, serta meningkatkan ruang sosial bagi masyarakat setempat, mengingat lingkungan pasar Astana Anyar merupakan kampung kota yang begitu guyub dan akrab satu sama lain. Selain itu, konsep Mix Use juga dapat memungkinkan adanya akses yang lebih memadai, yaitu dengan akses yang lebih luas yang akan memberikan kemudahan dan kenyamanan bagi masyarakat pasar Astana Anyar, terutama dalam mengatasi lingkungan perumahan sekitar pasar Astana Anyar yang terisolasi oleh keberadaan pasar.

\section{DAFTAR PUSTAKA}

[1] Bill Olner, M. M. (2009). HC 308-II Market Failure?: Can the traditional market survive? Communities and Local Government Committee, (July). Retrieved from https://publications.parliament.uk/pa/cm200809/cmselect/cmcomloc/308/308ii.pdf

[2] Newmark dan Thompson, 1977, Self, Space, and Shelter, Harper and Row Publisher, NewYork

[3] Suryadarma, D., \& Mcculloch, N. (2007). Impact of Supermarkets on Traditional Markets and Retailers in Indonesia's Urban Centers.

[4] Worpole, K., \& Knox, K. (2007). The Social Value of Public Spaces. Jrf.

APA. 2013. "Mixed Use Development," 76-79.

[5] Beyer, Paul. 2006. "Mixed-Use Zoning." Livable New York Resource Manual (Section II.2.g), 5.

[6] PAMELA, (University of the Sunshine Coast) WARDNER. 2014. "Explaining MixedUse Developments: A Critical Realist'S Perspective Pamela." 20Th Annual Pacific-Rim Real Estate Society Conference, 19-22.

[7] Speck, Lawrence. n.d. "The Importance of Mixed Use." 